\title{
REGIONAL VARIATION IN TOXOPLASMOSIS SERONEGATIVITY IN THE SÃO PAULO METROPOLITAN REGION.
}

\author{
A.C.S. GUIMARÃES(1), M. KAWARABAYASIII(1), M.M. BORGES(1,2), J.E. TOLEZANO(1) \& II.F. ANDRADE JR(2)
}

\begin{abstract}
SUMMARY
Toxoplasmosis is a highly prevalent zoonotic human infection caused by the Apicomplexa protozoon Toxoplasma gondii. The acute disease is usually mild or asymptomatic, except for foetal infection transmitted by acutely infected pregnant women, which courses as a devastating disease. In order to determine possible regional variations in risk factors, we studied the frequency of seronegativity in areas of the São Paulo Metropolitan Region, comparing titers and age groups. The prevalence of seronegativity was determined retrospectively in 1286 pregnant women receiving prenatal care at public health services in four selected areas of the São Paulo Metropolitan Region of similar socioeconomic background.

The São Paulo City area had the higher frequency of seronegativity $(41.1 \%)$, followed by the Northwest $(31.5 \%)$ and Southwest $(29.9 \%)$ areas, with similar intermediate levels, and by the Northeast $(22.5 \%)$ area with the lowest frequency $(p<0.001)$. A rough estimate disclosed about 280 infected infants/year in the São Paulo Metropolitan Region. Serological titers analyzed by age group suggested a decline in antibody levels with age, as shown by a lower frequency of higher titers in older groups. Our study emphasizes the importance of determining the regional prevalence of toxoplasmosis for proper planning of public health prenatal care.
\end{abstract}

KEYWORDS: Toxoplasmosis; Epidemiology; Serology; Foetal risk; Pregnancy

\section{INTRODUCTION}

Toxoplasmosis is a highly prevalent zoonotic human infection caused by the Apicomplexa protozoon Toxoplasma gondii ${ }^{3}$. The disease is transmitted by meat containing cysts or by contact with infective oocysts, excreted in the faeces of one of the definitive hosts such as the domestic cat ${ }^{5}$. The acute disease is usually mild or asymptomatic in immunocompetent hosts, but is devastating in immunocompromised hosts $\mathrm{s}^{6}$. If the acute infection occurs in a pregnant woman, it can be transmitted to the foetus in $60 \%$ of cases $^{8}$. This foetal disease may course like the Sabin tetrad caused by growth of the parasite in the CNS without an effective immune response, resulting in hydrocephaly, CNS calcifications, corioretinitis and mental retardation ${ }^{9}$. Thus, it has been estimated that one in 1000 births will be an infected child, with high social costs, estimated at 222 million dollars a year in the US ${ }^{8}$. The determination of the prevalence of this infection and its diagnosis are mandatory since treatment of acutely infected mothers is feasible and effective and can prevent foetal infection

(1) Seção de Parasitoses Sistêmicas - Instituto Adolfo Lutz. São Paulo, S.P, Brasil

(2) Laboratório de Protozoologia - Instituto de Medicina Tropical de São Paulo - FMUSP São Paulo, S.P., Brasil.

Address for correspondence: II.F.Andrade Jr, Lab.Protozoologia - Inst.Med. Tropical S.Paulo. Av. Dr. Enéas de Carvalho Aguiar, $470.05403-000$ São Paulo, S.P., Brazil. 
and the devastating disease that follows ${ }^{8}$. This prevalence could be estimated by serological surveys of specific anti-T.gondii antibodies ${ }^{6}$ and the information obtained could be used by health services to organize the prevention or early detection of foetal infection followed by immediate treatment. The objective of the present study was to determine the prevalence and titers of anti$T$. gondii antibodies in pregnant women receiving prenatal care at Public Health services in the São Paulo Metropolitan Region, and to compare titer frequency in four defined areas and age groups.

\section{METHODS}

\section{Population}

Sera for the detection of anti $T$. gondii IgG antibodies were obtained from 1286 pregnant women from the São Paulo Metropolitan Region during routine Public Health prenatal care in 1989 and 1990. The patients actively sought Public Health care and the tests were performed occasionally during pregnancy, according to a random distribution. We excluded 38 very young pregnant women (less than 16 years old) due to the small number of such subjects in some areas and titer groups.

The samples were divided into metropolitan areas as defined by the São Paulo State Public IIcalth Service.

The São Paulo City area comprised sera mainly from the East region of the county, in a large urban area. The Northwest Area consists of industrial cities (Osasco, Carapicuiba, Barueri and Jandira). The other two areas, which include rural zones, were the Southwest Area (Taboão da Serra, Embu and others) and the Northeast Area (Guarulhos and Arujá). Some social and sanitation data for these areas are shown in table 1.

\section{Immunofluorescence assays}

All serological tests were performed routinely at the Laboratório de Parasitoses Sistêmicas of Instituto Adolfo Lutz, São Paulo. We used a standard immunofluorescence assay for detection of anti-T.gondii human IgG antibodies in sera ${ }^{12}$. Briefly, tachyzoites, RH or N14 strain of T.gondii, were purified by differential centrifugation in phosphate buffered saline (PBS) from peritoneal exsudates of infected mice until less than $0.1 \%$ mammalian cell contamination was detected. After formalin fixation, tachyzoites were dried on microscope slides at 50 cells/field. Inactivated sera, diluted serially at $1 / 16,1 / 256,1 / 1024,1 / 1048$ and $1 / 4096$, were applied to the slide, incubated for $30 \mathrm{~min}$ at $37^{\circ} \mathrm{C}$ and carefully washed. Bound human IgG was detected using a fluoresceinated secondary antibody, sheep anti-human alpha-chain IgG (Biolab-Merrieux) incubated for $30 \mathrm{~min}$ at $37^{\circ} \mathrm{C}$, at appropriate dilutions. After washing, slides were observed by epifluorescence in a Zeiss microscope. Positive titers were considered as the last dilution presenting a clear and uniform fluorescent contour of the tachyzoite as a whole ${ }^{2}$. Speckled or nuclear patterns were not considered positive. Higher titers (>1024) were combined and considered as a single group.

\section{Data analysis}

Area frequencies were compared by the Chi-square test with Yates correction, and Pearson linear regression was used to compare evolution or decline of frequencies according to age group ${ }^{13}$.

\section{RESULTS}

The frequencies of anti-T.gondii IgG titers in the São Paulo Metropolitan Region and areas are shown in Table 2, according to five-year age groups.

Table 1

Some social and health parameters from areas on São Paulo Metropolitan Region

\begin{tabular}{|c|c|c|c|c|}
\hline Social and IIealth parameters & $\begin{array}{l}\text { São Paulo } \\
\text { City Area }\end{array}$ & $\begin{array}{c}\text { Northwest } \\
\text { Area }\end{array}$ & $\begin{array}{l}\text { Southwest * } \\
\text { Area }\end{array}$ & $\begin{array}{l}\text { Northeast * } \\
\text { Area }\end{array}$ \\
\hline $\begin{array}{l}\text { Treated water network } \\
(\mathrm{km} / 1000 \text { inhabitants })\end{array}$ & 1.385 & 1.216 & 1.272 & 1.524 \\
\hline $\begin{array}{l}\text { Sewage network } \\
\text { ( } \mathrm{km} / 1000 \text { inhabitants) }\end{array}$ & 0.824 & 0.465 & 0.129 & 0.543 \\
\hline $\begin{array}{l}\text { Infant death ratio } \\
\text { (deaths/ } 1000 \text { births) }\end{array}$ & 35.14 & 37.86 & 39.26 & 37.39 \\
\hline Natality (birth/1000 inhab) & 20.69 & 24.16 & 20.16 & 24.56 \\
\hline
\end{tabular}


GUTMARÃES,A.C.S. ; KAWARABAYASII,M. ; BORGES,M.M. ; TOLEZANO,J.E. \& ANDRADE JR.,H.F. - Regional variation in toxoplasmosis seronegativity in the São Paulo Metropolitan Region. Rev. Inst. Med. trop. S. Paulo, 35 (6): 479-483, 1993.

Table 2

IFA IgG anti T.gondii titers and age groups in pregnant women at São Paulo Metropolitan Region.

\begin{tabular}{|c|c|c|c|c|c|c|c|}
\hline \multirow[b]{2}{*}{ Areas } & \multirow[b]{2}{*}{ Titers } & \multirow[b]{2}{*}{ Total } & \multicolumn{5}{|c|}{ Age Groups } \\
\hline & & & $16-20$ & $21-25$ & $26-30$ & $31-35$ & $>36$ \\
\hline \multirow{4}{*}{ Northwest } & neg & 85 & 23 & 26 & 20 & 9 & 7 \\
\hline & $\%$ & 31.5 & 29.9 & 31.3 & 32.8 & 32.1 & 33.3 \\
\hline & $1 / 16$ & 83 & 18 & 29 & 16 & 11 & 9 \\
\hline & $\%$ & 30.7 & 23.4 & 34.9 & 26.2 & 39.3 & 42.9 \\
\hline \multirow[t]{7}{*}{ Area } & $1 / 256$ & 71 & 26 & 21 & 16 & 6 & 2 \\
\hline & $\%$ & 26.3 & 33.8 & 25.3 & 26.3 & 21.4 & 9.5 \\
\hline & $1 / 1024$ & 31 & 10 & 7 & 9 & 2 & 3 \\
\hline & $\%$ & 11.5 & 13 & 8.4 & 14.8 & 7.1 & 14.3 \\
\hline & Tolal & 270 & 77 & 83 & 61 & 28 & 21 \\
\hline & neg & 122 & 36 & 39 & 27 & 11 & 9 \\
\hline & $\%$ & 41.1 & 46.8 & 39.4 & 39.7 & 36.7 & 39.1 \\
\hline \multirow[t]{2}{*}{ São Paulo } & $1 / 16$ & 82 & 19 & 31 & 15 & 7 & 10 \\
\hline & $\%$ & 27.6 & 24.7 & 31.3 & 22.1 & 23.3 & 43.5 \\
\hline \multirow[t]{2}{*}{ City } & $1 / 256$ & 77 & 19 & 23 & 22 & 9 & 4 \\
\hline & $\%$ & 25.9 & 24.7 & 23.2 & 32.4 & 30 & 17.4 \\
\hline \multirow[t]{5}{*}{ Area } & $1 / 1024$ & 16 & 3 & 6 & 4 & 3 & 0 \\
\hline & $\%$ & 5.4 & 3.9 & 6.1 & 5.9 & 10 & 0 \\
\hline & Total & 297 & 77 & 99 & 68 & 30 & 23 \\
\hline & neg & 64 & 21 & 14 & 22 & 4 & 3 \\
\hline & $\%$ & 22.5 & 24.7 & 18.2 & 31.4 & 12.9 & 14.3 \\
\hline \multirow[t]{2}{*}{ Northeast } & $1 / 16$ & 97 & 23 & 26 & 22 & 14 & 12 \\
\hline & $\%$ & 34.2 & 27.1 & 33.8 & 31.4 & 45.2 & 57.2 \\
\hline \multirow[t]{7}{*}{ Area } & $1 / 256$ & 101 & 33 & 35 & 18 & 11 & 4 \\
\hline & $\%$ & 35.6 & 38.8 & 45.5 & 25.7 & 35.5 & 19 \\
\hline & $1 / 1024$ & 22 & 8 & 2 & 8 & 2 & 2 \\
\hline & $\%$ & 7.7 & 9.4 & 2.6 & 11.4 & 6.5 & 9.5 \\
\hline & Total & 284 & 85 & 77 & 70 & 31 & 21 \\
\hline & neg & 118 & 41 & 41 & 22 & 8 & 6 \\
\hline & $\%$ & 29.9 & 32.5 & 32.3 & 28.2 & 21.6 & 22.2 \\
\hline \multirow[t]{2}{*}{ Sout hwest } & $1 / 16$ & 91 & 20 & 30 & 19 & 14 & 8 \\
\hline & $\%$ & 23 & 15.9 & 23.6 & 24.4 & 37.8 & 29.6 \\
\hline \multirow[t]{7}{*}{ Area } & $1 / 256$ & 144 & 54 & 41 & 26 & 12 & 11 \\
\hline & $\%$ & 36.5 & 42.6 & 32.3 & 33.3 & 32.4 & 40.7 \\
\hline & $1 / 1024$ & 42 & 11 & 15 & 11 & 3 & 2 \\
\hline & $\%$ & 10.6 & 8.7 & 11.8 & 14.1 & 8.1 & 7.4 \\
\hline & Total & 395 & 126 & 127 & 78 & 37 & 27 \\
\hline & neg & 389 & 121 & 120 & 91 & 32 & 25 \\
\hline & $\%$ & 31.2 & 33.2 & 31.1 & 32.9 & 25.4 & 27.2 \\
\hline \multirow[t]{2}{*}{ São Paulo } & $1 / 16$ & 353 & 80 & 116 & 72 & 46 & 39 \\
\hline & $\%$ & 28.3 & 21.9 & 30.1 & 26 & 36.5 & 42.4 \\
\hline \multirow[t]{2}{*}{ Metropolitan } & $1 / 256$ & 393 & 132 & 120 & 82 & 38 & 21 \\
\hline & $\%$ & 31.5 & 36.7 & 31.1 & 29.6 & 30.2 & 22.8 \\
\hline \multirow[t]{3}{*}{ Region } & $1 / 1024$ & 111 & 32 & 30 & 32 & 10 & 7 \\
\hline & $\%$ & 8.9 & 8.8 & 7.8 & 11.6 & 7.9 & 7.6 \\
\hline & Total & 1246 & 365 & 386 & 277 & 126 & 92 \\
\hline
\end{tabular}

The seronegativity expressed in the absence of antiT.gondii IgG in sera had an overall frequency of $31.2 \%$ in the São Paulo Metropolitan Region. The defined areas presented similar age distributions for pregnant women. The seronegativities of the various areas were different, with São Paulo City presenting the higher seronegativity,
$41.1 \%$, significantly different from all other areas $(\mathrm{p}<0.001)$. The Northwest and Southwest areas presented similar intermediate levels, $31.5 \%$ and $29.9 \%$, and the Northeast area presented the lowest seronegativity, $22.5 \%$. The social and sanitation indexes analyzed had no correlation with the disparities observed. The fre- 
quency of low titers (1/16) increased with age groups in most regions, and was clearly seen in the older group, despite a relatively stable 5 to $10 \%$ frequency of high titers (1/1024 or higher) regardless of age group or region.

The age distribution of seronegativity frequency in different areas is shown in Figure 1. The seronegativity frequencies presented a clear decline with age in most areas despite different quantitative levels in each.

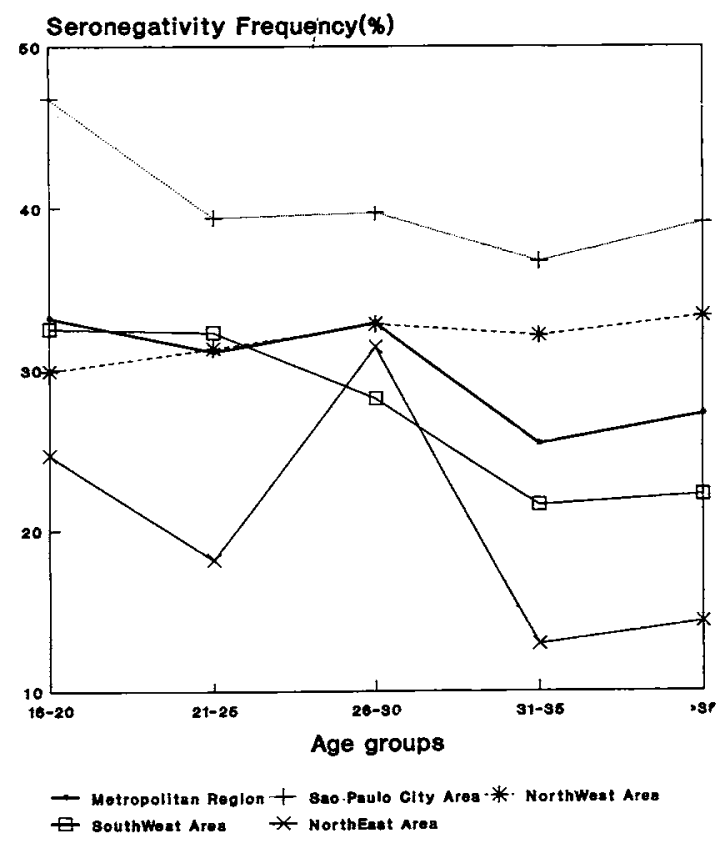

Fig. I - Seronegativity frequency of anti $T$. gondii $\operatorname{IgG}$ according to age groups in São Paulo Metropolitan Region and areas.

\section{DISCUSSION}

This work shows the prevalence of anti-T.gondii antibodies by IFA tests in pregnant women in the São Paulo Metropolitan Region and areas. It has been reported that the test used in this survey, the IFA, presents greater specificity than other serological tests such as the dye binding or hemagglutination tests ${ }^{\prime}$. Despite its specificity, the IFA test has been reported to be less efficient in the detection of low levels of antibodies present in older women infected much earlier in life ${ }^{11}$, as also suggested by our results, which presented a clear elevation of frequency of low titers with increasing age groups. This fact may impair an exact mathematical analysis of prevalence for the evaluation of relative incidence and only rough attempts were made here by determining seronegativity prevalence, although some reports of mathematical models based on this approach are available ${ }^{7}$. According to this rough estimation, by correlating seronegativity in young age groups $(21-25)$ and older age groups (31-35) with time between groups, we obtained a $0.57 \%$ crude risk of contracting toxoplasmosis in one year. Analyzing other components such as birth rate reported by São Paulo Public Health Secretary for the metropolitan area $(22 \%)$, prevalence of seronegative tests (31.2), risk of congenital transmission $(60 \%)^{8}$ and pregnancy duration $(0.75 \mathrm{y})$, we could estimate a congenital toxoplasmosis incidence of 0.8 infected children/1000 births, representing 280 new cases per year, in the whole population.

Taken as a whole, our data show that the prevalence of seronegative pregnant women varied with urban area, but we could not ascribe these variations to the social and health parameters shown in Table 1. Some new factors are involved in toxoplasmosis transmission, such as increased consumption of frozen meat and greater urbanization ${ }^{4}$. The freezing process affects the viability of T.gondii tissue cysts, reducing this source of infeccion. Advanced urbanized areas such as the São Paulo City area present a higher frequency of seronegativity than other areas comprising rural zones, where livestock for human consumption is locally produced.

An early diagnosis and effective therapy could restrain congenital transmission and foetal effects, but few tests are performed on our pregnant women. Frequently, only one sample was collected throughout pregnancy, without any follow-up of seronegative pregnant women.

We emphasize the need for careful prenatal care, with follow-up of anti-T.gondii IgG negative pregnant women by multiple sampling during pregnancy, to obtain an early diagnosis of a treatable devastating foetal disease.

The regional variation found in this study indicates areas in the São Paulo Metropolitan Region where educational programs should be implemented to prevent infection of pregnant women.

\section{RESUMO}

\section{Variação regional na soronegatividade para toxoplasmose na região metropolitana de São Paulo.}

Toxoplasmose é uma infeç̧ão zoonótica humana de alta prevalência, causada por um protozoário 
Apicomplexa, Toxoplasma gondii. A evolução da doença aguda é geralmente leve ou assintomática, exceto nas infecções agudas das gestantes, quando a infecção fetal causa uma doença devastadora. Para determinar se haveriam fatores de risco regionais, foi analisada a frequência de títulos de anticorpos anti$T$.gondii em áreas na região Mctropolitana de São Paulo, comparando grupos etários. Esta frequência de soronegatividade foi determinada retrospectivamente $\mathrm{em} 1286$ gestantes que procuraram os serviços públicos para exames pré-natais da região metropolitana de São Paulo, usando um teste de imunofluorescência indireta para IgG anti- $T$.gondii, em quatro áreas selecionadas, com infraestrutura e condições sociais semelhantes.

A área da cidade de São Paulo apresentou a maior frequência de soronegatividade $(41,1 \%)$, seguida pelas áreas Noroeste $(31,5 \%)$ e Sudoeste( $29,9 \%)$, com niveis intermediários semelhantes, e a área Nordeste $(22,5 \%)$. com a menor frequência $(p<0,001)$. Uma estimativa grosseira permite estimar $\mathrm{cm}$ cerca de 280 crianças infectadas por ano na Região Metropolitana de São Paulo. A análise dos títulos sorológicos por grupos etários sugere uma queda de seus valores com a idade, mostrada pela menor frequência de titulos elevados em grupos de maior idade.

Este estudo enfatiza a importância da determinação da prevalência regional de toxoplasmose, para dimensionar adequadamente os serviços e cuidados de saúde pré-natal, na rede pública.

\section{ACKNOWLEDGMENTS}

We are grateful to Roselaine A. P. Cardoso, José R. Coelho and Maria L. Raymundo for technical assistance.

This work was partially supported by LIMIICFMUSP (LIM-49).

\section{REFERENCES}

1. AL-MESHARI, A.A.; CHOWDHURY, M.N.H.; CHATTOPADHYAY, S.K. \& DE SILVA, S.K. - Screening for toxoplasmosis in pregnancy. Int. J. Gynaec. Obstet.,29:39-45, 1989.

2. CAMARGO, M.E. \& LESER, P.G. - Diagnostic information from serological tests in human toxoplasmosis. II - Evolutive study of antibodies and serological patterns in acquired toxoplasmosis, as detected by hemagglutination, complement fixation, IgG and IgM immunofluorescence tests. Rev. Inst. Med. trop. S.Paulo, 18:227238,1976

3. DUBEY, J.P. - Toxoplasma gondii. In: KREIER, J.P., ed. Parasitic protozoa. New York, Academic Press, 1977. v.3, p.102-165.

4. FRENKEL, J.K. - Diagnosis, incidence and prevention of congenital toxoplasmosis. Amer. J. Dis. Child., 144:956-957, 1990.

5. FRENKEL, J.K.; DUBEY, J.P. \& MILLER, N.L. - Toxoplasma gondii: fecal stages identified as coccidian oocysts. Science, $167: 893-896,1970$

6. GLEASON, T.H. \& ILAMLIN, W.B. - Disseminated toxoplasmosis in the compromised host. Arch. intern. Med., 134:1059-1062, 1974.

7. PAPOZ, L.; SIMONDON,F; SAURIN,W. \& SARMINI, H. - A simple model relevant to toxoplasmosis applied to epidemiologic results in France. Amer. J. Epidem., 123:154-161, 1986.

8. REMINGTON, J,S. \& DESMONTS, G. - Toxoplasmosis. In: RSMINGTON, J.S. \& KLEIN, J.O.,ed. Infectious diseases of the fetus and newborn infant. 3.ed. Philadelphia, W.B.Saunders, 1990. p. 89-194

9. SABIN, A.B. - Toxoplasmic encephalitis in children. J. Amer. med. Ass., 116:801-807, 1941.

10. SEVER, J.L.; ELLENBERG, J.II; LEY, A.C.; MADDEN, D.L.; FUCCILLO, D.A.; TZAN, N.R. \& EDMONDS, D.M. Toxoplasmosis: maternal and pediatric findings in 23000 pregnancies. Pediatrics, 82:181-192, 1988.

11. van DRUTEN, II; van KNAPEN, F. \& REINTJES, A. Epidemiologic implications of limited-duration seropositivity after Toxoplasma infection. Amer. J. Epidem., 132:169-180, 1990.

12. WALTON, B.C.; BENCHOFF, B.M. \& BROOKS, W.II. Comparison of indirect fluorescent antibody test and methylene blue dye test detection of antibodies to Toxoplasma gondii. Amer. J. trop. Med. Ilyg., 15:149-152, 1966.

13. WOOLSON, R. F. - Statistical methods for the analysis of biomedical data. New York, John Wiley \& Sons, 1987.

Recebido para publicação em 25/02/1993

Aceito para publicação em 28/07/1993 